\title{
How Private High Schools Deal With Multiculturalism Issues in Surabaya After Terrorists Bombing
}

\author{
Putri Aisyiyah Rachma Dewi* \\ Communication Science Department, \\ Faculty of Social Sciences and Law \\ Universitas Negeri Surabaya \\ Surabaya, Indonesia \\ putridewi@unesa.ac.id
}

\author{
Awang Dharmawan \\ Communication Science Department, \\ Faculty of Social Sciences and Law \\ Universitas Negeri Surabaya \\ Surabaya, Indonesia \\ awangdharmawan@unesa.ac.id
}

\author{
FX Sri Sadewo \\ Department of Sociology, \\ Faculty of Social Sciences and Law \\ Universitas Negeri Surabaya \\ Surabaya, Indonesia \\ fsadewo@unesa.ac.id
}

\begin{abstract}
Indonesia is a multicultural country, likewise all the citizens and the social institutions, such as school. When terrorists bombs some curches in Surabaya in 2018, the living in peace-situation of the city are distracted. The bombs blasted in places near of two private high schools, i.e. the educational institution that is managed by religion-based comittee, one is Islamic high school and another one is Catholic high school. While the city-dwellers are shocked by this situation, these two educational institutions have responsibilities to manage the anxiety and diversity between their students, in order to make the youngers feel safe and grow as multicultur persons. Moreover, this great responsibility is in line with the condition of their students who have different religious backgrounds. This research is focused on how the diversity in these private schools are managed. The research method is case study, and the information are gained by in depth interview for the teachers and pupils. The results show both of schools manage the diversity mainly by personal approach and liberate all students to practice and express their beliefs in schools.
\end{abstract}

Keywords: multiculturalism, diversity, anxiety

\section{INTRODUCTION}

Multiculturalism become a main value that is hold by the founders, government, social institutions, and all of the citizens of Indonesia. The history shows how people from different sub-cultures, religions, and ethnics made a concensus to became one nation and one country, Indonesia. They consciusly fighted against colonials then proclaimed the independence, choose Indonesia as a name for this new country, which is delivered from sanskrit words and the meaning is united of archipelagos.

Multiculturalism is characterized by various identities of each communities in it. Indonesia represents the idea of multiculturalism because each islands have ethnic and cultural variants, furthermore they also have a dominant ethnic group, minorities, as well as religion and beliefs [1].

However, the term "multicultur" still being a problem since in very beginning. Although it was agreed to become a nation at the time of the Youth Pledge in the Second Youth Congress, 28 October 1928. [2], [3] but it was easily found the situations that are contrast with the idea of inclusivity (i.e. the core of being multiculture is being inclusive to people from different groups).

The founding fathers of Indonesia, including President Soekarno and the Vice President Mohammad Hatta, ratified Pancasila as an ideology of this new state. Pancasila has five principles that is relevant with multiculturalism values, and the most significant one is the first principle: believe in one and only God. It is stated only "God" without any term refers to specific religion.[4]

Consequently, there are five monotheism beliefs which are acknowledged as legal religions in Indonesia, namely Islam, Catholic, Protestant, Hinduism, and Buddha. Recently, Confusius is also recognized as legal belief. In Soeharto era, the next President after Soekarno, all the citizens are forced to choose one of legal religions. [5], [6] There is no place for local religion or any other beliefs. For an example, Dayak as a sub-culture in Kalimantan, the largest Island in Indonesia, has its own belief, but Dayak people can not claimed and practiced their belief, they should choose whether they will be a moslem, christian, buddhist, or hindu. [7] So did Tengger sub-culture in East Java. [8]

Furthermore, the Seharto's regime emphasized the principle of Unity in Diversity. Any person who dread with cultural differences, will be considered as a lawbreaker. (s)he will be sanctioned according to SARA issues. SARA is the abbreviation for tribes, religions, races, and inter-groups. This acronym is used in negative meaning to all the things related with a threat for national security because focusing on the differences in spite of the similarities.

In education system, the government try to simplified and regulate the management of schools. Through the ministry of education and culture, the government developed two kinds of educational institutions: public schools and private schools. Public school institutions are funded by the government, and private schools are maintaned by nongovernment organisations, usually religion-based bodies. Nevertheless, both of schools should respect the diversity of 
their students as long as they are monotheism believers, according to first principle of Pancasila.

In contrast to secular countries, such as the United States and a number of countries in Europe, [9], [10] religious educations are still taught, both in public schools and in faith-based schools in Indonesia. The differences of both school-systems are the time for religion subjects in the curriculum, the school uniforms, and some of religious practices such as shalat or praying time for moslem and liturgical worship for christians. Religious subject spends more time in religion-based schools than in public shools. The Islamic school's uniform is long skirt for girl, meanwhile in public or christiany school is midi-skirt. Both Islamic and Christiany schools have a regular prayer-times every day, the students and the teachers usually pray together before the class is started and after the class is over.

In practice, the proportion of student's backgrounds in general schools follows the demographic structure of the local community. If the majority is moslem, then most of the students are Muslim, as well as in areas with a diversity of dominant religions, e.g. in Eastern Indonesia, the majority are Christians, while Balinese people are Hindu. In addition, religious based schools naturally follow the pattern of religious culture as described by Clifford Geertz. [11]

Towards the reformation era, when the Soeharto regime was forced down and afterwards, the relationship between religious education and culture had a new face, especially in state schools. The excitement of religious life gives a new look to uniforms and learning. The curriculum design and the uniforms are tend to follow the dominant religion, Islam. The most visible things is the girls appearance which more and more female students wear veils or hijab. Since 2002, when Hijabers community was established in Indonesia, this fashion item is not only valued as religious practice but also as a lifestyle.[12]

in 2018 Surabaya experienced bomb attacks in three churches (05/13/2018) and police headquarters $(05 / 14 / 2018)$. In its history, this great city has never experienced such a thing, so it is not only shocking the victims and their families, but also to all the city-dwellers. For minority ethnic or religious groups, this chaos condition was confusing and make them live in panic situation. However, when terrorism occurred, the fearness quickly spread to all Surabaya people. That uncertainty begins with empathy for the victim on the one hand. On the other hand, they are supsicious and skeptical with other persons, either their acquitances or strangers. They scared if someone will do a terror act because of religious reason. Non-moslem persons avoid to interact with moslems, particularly who wear hijab or other moslem-style fashions.

Meanwhile the city-dwellers are shocked by this situation, the educational institutions have responsibilities to manage the anxiety and diversity, in order to make the youngers feel safe and grow as multicultur persons. According to the explanation, it is important to know how the private schools manage the anxiety bertween their inter-cultural and interreligion students.

This research takes places in two private high schools. First is Islamic school and the second is catholic high school.
Both of them are nearest schools from the location of Surabaya's bomb attacks. As informants, researchers conducted interviews with teachers and students. The observational data and in-depth interviews were processed qualitatively.

\section{RESULT AND DISCUSSION}

Looking for a reputable school. In the last few decades, through legislation to the Ministry of National Education (minister of national education regulation), the government has standardized. Standardization is regulated starting from the competence of graduates, [13] content, [14] processes [15] to assessment. [16] The government also develops management patterns for schools, and also regulates the quality of teachers who are supposed to teach. To ensure this, through the national school/madrasah accreditation body (BAN S / M), the government gives guarantees to the public about the quality of the implementation of schools / madrasah. In short, with this process it is certain that every school has the same standard.

But in reality, this is not fully understood by the public. This is evident from the view of the public who still see there are two castes according to the degree of popularity: favourite and non-favourite schools.

Favourite schools are usually public shools, even some of privates schools also become favourite ones. Educational institution which is run by the government is more popular and demanded because of several things: first, the school has complete facilities; second, learning is carried out by professional teachers. [17] Third, because the operational costs are funded by the government, so it is totally free for students.

To educate the religious-values to their children, parents have options to educate by themselves or send their childs to informal-religion institution, usually held by the mosque foundation near their home, or they can combine both ways.

For private school, which collects money from students, it is not an easy way to be the favourite one. Usually it is only choosen by students who are not accepted in public high school, so that they are contsrained to entering the private school. Nevertheless, some of non-government school have a prestigious label as a favourite school in town. This kind of institution are completed by great amenities for students, modern classrooms and facilities, and bilingual languages.

In spite of the visible-things reason, another cause is deal with shaping the character of teenagers. Parents who send their children to the religion-based schools also hope they will grow as religious persons in the future. They want a safe learning-environment surrounds by religious teachers and classmates that share similar beliefs.

Quality also concerns the character that the schools want to build. This was recognized by one of the religious teachers in one of the schools under a religion-based foundation when explaining variants of students, especially in matters of religion. "In our place, not all of them have the same religion. The amount is not too large. Their parents already know. They like it because their children's character is different from public schools. "The teacher said that their 
graduates have a distinctive character, namely: love, honesty, and hard work.

Diversity as a Gift. This sentence might be something that can be captured from the board of the high schools in this research when they are asked about facing diversity of their students. Regarding ethnic and cultural issues, diversity might not a big problem, for an example public and private schools in North Surabaya have a large number of Madurese students. In addition, there were also ethnic Chinese students. The variations in skin color and language can indeed trigger acts of bullying or harassment. Therefore, to prevent this, the class teacher is the key person for supervision.

The situation is contrast related to religious-diversity context. The problem is more complex and difficult. They should be more careful to make a policy or a treatment for their different-religion students, because the society and government give more concern for this issue. Multiculture society which is characterized by inclusive attitude become the biggest dream of this country.

This research found that private schools also accept students with various religious backgrounds. Although the schools are managed by religion-based organization and was build to strengthen religious values of the younger generation, but they are open for teenagers that came from different religions. In Catholic high school, the subject of this study, moslem students approximately 10 percent or less, and in Islamic school, they have less about 5 percent of all the students.

Before the 1990s, in order to facilitated the pupils to study religion subject, there were a number of schools that grouped minority students in one class. Take an example, a Catholic school in Surabaya, they made a "minority-class" which is most of the class members are moslem and some of them are minority religion (neither catholic or moslem). Meanwhile, in Islamic school, it also has its minority class too. When studying Islam, the non-moslem students can leave the class, they can have a leisure time in the library or do other activities. If Islamic subjects are placed at the last hour, then they can go home earlier. The schools also inviting the religion-subject teachers in the class. They attend the school regularly to teach and to give a preaching. The principal contacted the church or the department of religion's office to a teacher. The teachers are paid every time they come. Another strategy, the principal, through the curriculum vice-principal asked parents to involve their children in Sunday school. Sunday school teachers are asked to submit grades at the end of the semester. This last strategy is usually carried out by the elementary school management. However, there are weaknesses, that the builder of the Sunday school does not necessarily have a teacher (religious) educational background.

The current pattern is different. They, the principal along with the school-staff, did not make a special class. All nonMuslim students are spread out in the whole classes. The pattern remains the same, the moslem pupils come out when the subject is christianity. Usually the schedule is every Friday, when moslem do their Friday-salat. Another policy is celebrating feast day, usually the schools will invite the different-students to join the celebration. On that occasion, they also share foods and happiness to all the school members whatever their beliefs.

According to the terrorism incidents in Surabaya, there are several interesting findings. First, even the bomb blasted near their school but both of teachers and students fully believed to their "different friends". They already know that there are some people who joined with terrorist movement, but they perceived that their friends (and also the families) are in different group. They still make a friendship, working together on a homework or other assignments, and so on. Everything is going as well as before the terrors happen.

Different response came from the parents. According to an asnwer from student in Catholic school when asked about their feeling and interesting experiences during the panictime, she tells at that time her parents give so many advices about how to make a "proper" relationship with moslem friends, avoid too close with them. She was also asked to bring a veil to covered her head when it is needed. The things that never happen to her before terrorism was occurred.

Dealing with this anxiety, schools are use the counselor teacher to do personal approach to the students. The counselors are in one team. All of them should focus to understand the fearness and anxiety of their students. The counselors have a regular schedule to visit the classes alternately.

Counselor from Islamic-school says she already know that being a teenager-counselor is a nuisance because the big responsibilty, but she enjoy the job and having such a invaluable experience when she know that her presence is significant in her student's life-journey.

The catholic counseler have similar answer that she also feel blessed when she know that she is meaningful for her students. She is happy when the youngsters believe in her and share their fearness, emotions, and anxiety to her. She always wants to do so many things to make them feel better and secure in this world.

\section{CONCLUSION}

This research explains that the bomb-blast in Surabaya affected the students anxiety and fearness. The school manage it by doing personal approach to the students. The existence of counselor teachers are very important in building inter-cultural relationships between the students who are minorities in religion-based schools.

The counselor communicate regularly with the students to make them feel comfort and secure even they are minorities. They also help the majority group to maintain trust and empathy to their minority friends. Hence, everyone can express and actualize their beliefs in their communities freely. 


\section{REFERENCES}

[1] D. A. Phillips, Indonesia, 1st ed. Philadelphia: Chelsea House Publishers, 2005.

[2] A. Vickers, A History of Modern Indonesia, 1st ed. Cambridge: Cambridge University Press, 2005.

[3] M. C. Ricklefs, A History of Modern Indonesia since c. 1200, 4th ed. Hampshire: Palgrave Macmillan, 2008.

[4] C. Brown, A Short History of Indonesia. The Unlikely Nations?, 1st ed. Crows Nest, NSW: Allen \& Brown, 2003.

[5] J. Betrand, Nationalism and Ethnic Conflict in Indonesia, 1st ed. Cambridge: Cambridge University Press, 2004.

[6] A. Schwarz, A Nation in Waiting: Indonesia's Search for Stability, 2nd ed. Colorado: Westview, 2004.

[7] S. Djuweng, "Orang Dayak, Pembangunan dan Agama Resmi," in Kisah dari Kampung Halaman. Masyarakat Suku, Agama Resmi dan Pembangunan, 1st ed., T. Sumartana, E. Darmaputera, D. Effendi, D. Dhakidae, Z. Lubis, H. HS Salim, A. Suedy, E. Sarapung, and Z. Qodir, Eds. Yogyakarta: Pustaka Pelajar, 1996, pp. 3-36.

[8] R. W. Hefner, "Islamizing Java ? Religion and Politics in Rural East Java," J. Asian Stud., vol. 46, no. 3, pp. 533-554, 2008.

[9] R. M. Thomas, Religion in Schools: Controversies around the World, 1st ed. Westport, CT: Praeger Publisher, 2006.

[10] A. Marzilli, Religion in Public Schools, 1st ed. Philadelphia: Chelsea House Publishers, 2004.

[11] C. Geertz, The Religion of Java, Phoenix Ed. Chicago and London: The University of Chicago Press, 1976.

[12] E. Turmudi, "The Passion of Jilbab : Socio-Cultural Transformation of Indonesian Muslim Women," Int. J. Sci. Res. Publ., vol. 6, no. 5, pp. 287-292, 2016.

[13] M. P. dan K. Indonesia, Peraturan Menteri Pendidikan dan Kebudayaan No. 20 tahun 2016 tentang Standard Kompetensi Lulusan Pendidikan Dasar dan Menengah. Indonesia, 2016.

[14] M. P. dan K. Indonesia, Peraturan Menteri Pendidikan dan Kebudayaan No. 21 tahun 2016 tentang Standard Isi. Indonesia, 2016.

[15] M. P. dan K. Indonesia, Peraturan Menteri Pendidikan dan Kebudayaan No. 22 Tahun 2016 tentang Standard Proses. Jakarta, Indonesia: BNSP, 2016.

[16] M. P. dan K. Indonesia, Peraturan Menteri Pendidikan dan Kebudayaan No. 23 tahun 2016 tentang Standard Penilaian. Indonesia, 2016.

[17] BNSP, "Standar Pendidik dan Tenaga Kependidikan," BNSP, 2017. [Online]. Available: http://bsnpindonesia.org/standar-pendidikan-dan-tenaga- kependidikan/. [Accessed: 16-Aug-2019].

[18] P. R. Indonesia, Undang-Undang Dasar Negara Republik Indonesia Tahun 1945. 2013.

[19] A. Faisal, "Protes Sistem Zonasi PPDB, Wali Murid di Surabaya Minta Mendikbud Dicopot," Kompas, Surabaya, 19-Jun-2019.

[20] I. N. Asih, "Pendidikan Agama bagi Peserta Didik Muslim di Lembaga Pendidikan Non Muslim (Studi Deskriptif di SMA BOPKRI 1 Pati Tahun Ajaran 2014/2015)," Universitas Islam Negeri Walisongo, 2015 . 